\title{
Estrus Performance and Pregnancy Rate in Types of Local Cows on Different Estrus Synchronization Protocols
}

\author{
Yendraliza*, Lia, Jully Handoko and Anwar Efendi Harahap \\ Faculty of Agriculture and Animal Science, Universitas Islam Negeri Sultan Syarif Kasim Riau, Pekanbaru, Indonesia \\ *Corresponding author email: yendraliza@uin-suska.ac.id
}

\begin{abstract}
The research aimed to evaluate the onset of estrus, conception rate, pregnancy rate and duration of estrus in Bali cow, limousine cow and rambon cow after being administered with three different hormones to syncrhronize estrus. A randomized block design with two factors, type of cow and hormone dose, was performed. Fifty-four postpartum cows consisted of the three breeds were administered to a single dose of $\mathrm{PGF}_{2} \alpha\left(5 \mathrm{ml}\right.$ per cow), a double dose of $\mathrm{PGF}_{2} \alpha\left(10 \mathrm{ml}\right.$ per cow) and combination of $\mathrm{PGF}_{2} \alpha$ and hCG (1,500 IU per cow). An analysis of variance showed that different breeds did not associate with the hormone doses and their combination, as evident from the onset of estrus, duration of estrus, conception rates and service per conception. However, different cow breeds showed the same onset of estrus, service per conception and the different onset of estrus and pregnancy rates. On the other hand, different doses of $\mathrm{PGF}_{2} \alpha$ and its combination with hCG generated different onset of estrus, duration of estrus, and pregnancy rates, but shared common service per conception. In conclusion, Bali cow demonstrated a more appropriate fertility than Limousin cow and Rambon cow. A combination of PGF $_{2} \alpha$ and hCG showed the most adequate hormonal treatment to synchronize the estrus compared to single and double doses of $\mathrm{PGF}_{2} \alpha$.
\end{abstract}

Keywords: conception rate, duration of estrus, pregnancy rate, the onset of estrus

Abstrak. Penelitian bertujuan untuk melihat pengaruh jenis hormon sinkronisasi yang berbeda terhadap kecepatan estrus, lama estrus, angka kebuntingan dan service per conception pada sapi Bali, sapi Limousin dan sapi Rambon. Penelitian ini menggunakan Rancangan Acak Kelompok dua faktor. Faktor pertama menggunakan 54 ekor sapi betina pascapartus yang terdiri dari sapi Bali, sapi Limousin dan sapi Rambon sebagai. Faktor kedua adalah metode sinkronisasi yang terdiri dari; a. $\mathrm{PGF}_{2} \alpha$ dosis tunggal. b. Dosis ganda PGF2 $\alpha$ dan c. kombinasi PGF $2 \alpha$ dan hCG sebagai. Dosis PGF $_{2} \alpha$ yang digunakan adalah $5 \mathrm{ml} /$ ekor dan dosis hCG adalah 1500 IU/ekor. Parameter yang diukur adalah kecepatan munculnya estrus, durasi estrus, angka kebuntingan dan service per conception. Uji keragaman dilakukan terhadap data yang diperoleh. Hasil penelitian menunjukkan bahwa jenis sapi yang berbeda tidak berhubungan dengan metode sinkronisasi yang berbeda terhadap kecepatan munculnya estrus, durasi estrus, angka kebuntingan dan angka service per conception. Jenis sapi yang berbeda menghasilkan kecepatan munculnya estrus dan angka service per conception yang sama, durasi estrus dan angka kebuntingan yang berbeda. Metode sinkronisasi yang berbeda menghasilkan kecepatan munculnya estrus, durasi estrus dan angka kebuntingan yang berbeda tapi memiliki angka service per conception yang sama. Sapi Bali memiliki fertilitas yang lebih baik dari sapi Limousin dan sapi Rambon dengan metode sinkronisasi yang terbaik adalah kombinasi PGF $_{2} \alpha$ dan hCG dibandingkan single dan double dosis $\mathrm{PGF}_{2} \alpha$.

Kata kunci : angka kebuntingan, angka perkawinan, durasi estrus, kecepatan munculnya estrus

\section{Introduction}

The low productivity of beef cattle in rural areas is a major problem for Indonesian farmers as observed from the length of calving intervals and the slow pace of livestock puberty in the countryside. Most people in the countryside raise cattle traditionally. Bali cattle and Rambon cattle are Indonesia's local cows that demonstrate good reproduction.
They can live with minimum feed and are resistant to estrus (Purwantara et al., 2012). Bengkalis is one of the beef cattle development areas in Riau Province with up to 15,077 beef cattle including $45 \%$ productive female (BPS Bengkalis, 2017). However, cattle population did not significantly grow from $2015(14,807)$ to $2016(15,077)$ due partly to calving interval and the late first mating after 
calving. One of the solutions is artificial insemination that has evidently improved reproductive efficiency in livestock (Toelihere, 1985). However, the implementation of artificial insemination requires many livestock recipients with simultaneous estrus. The variation of the estrus cycle between individual livestock makes it difficult to apply in the field. Therefore, it is necessary to have reproductive technology that can equalize or synchronize estrus in cattle. Synchronization is a reproductive technology that allows simultaneous heat in livestock.

Estrus synchronization in livestock usually employs synthetic luteotropic hormones such as $\mathrm{PGF}_{2} \alpha$. The right dose of $\mathrm{PGF}_{2} \alpha$ hormones must be administered timely to get the maximum effect (Toelihere, 1985). The hormones use at the beginning or end of the luteal phase will reduce the effectiveness of these hormones (Jainudeen and Hafez, 2016a). Moreover, $\mathrm{PGF}_{2} \alpha$ for Bali cattle potentially triggers an estrus response (100\%) and pregnancy rate by $56 \%$ (Saili et al., 2017), whereas hCG for buffaloes results in a recurrent mating that increases pregnancy rate up to $91 \%$ (Akhtar et al., 2013). To date, studies on estrus response and conception rates from the use of various synchronization hormones with different types of cattle in Bengkalis are non-existent.

This study aims to investigate the effect of synchronization hormones used on the speed and duration of estrus, pregnancy rate and $(\mathrm{S} / \mathrm{C})$ in Bali cattle, Limousin cattle, and Rambon cattle.

\section{Materials and Methods}

The research was carried out in smallholder farms at Langkat Village, Siak Kecil Subdistrict, Bengkalis. The analysis used eighteen calved cows from each of three breeds (Bali, Limousin, and Rambon) with average weight of $254.8 \mathrm{~kg}$ and $2.5-3$ body condition score (BCS). The cows were placed in the farmer's cage at night and grazed on oil palm plantations to feed on grass and concentrates. Drinking water was provided ad libitum on oil palm plantations and in cages. The cattle were selected after rectal palpation by related officers from the Department of Agriculture and Animal Husbandry Bengkalis to ensure that they were not conceiving.

\section{Research Method}

This study employed two factorial Randomized Block Design (RBD) with 3 replications. The first factor was three local breeds, i.e. Bali, Limousine, and Rambon Cattle. The second factor was the synchronization method of three doses, namely single injection of $\mathrm{PGF}_{2} \alpha$, double injection of $\mathrm{PGF}_{2} \alpha$, and a combined injection of $\mathrm{PGF}_{2} \alpha$ on the first day and hCG on the eleventh day of artificial insemination. The single dose of $\mathrm{PGF}_{2} \alpha$ (LutalyseTM, Pharmacia and Upjohn Company, Pfizer Inc.) was 5 $\mathrm{ml} /$ livestock. The insemination was performed after cattle showed estrus using $0.25 \mathrm{ml}$ semen from BIBD (Balai Inseminasi Buatan Daerah) - the regional center of artificial insemination Center - Tenayan Raya, Riau.

\section{Research Implementation}

The cows were grouped according to their body condition score (BCS). The first group was injected with $5 \mathrm{ml} \mathrm{PGF}{ }_{2} \alpha$ intramuscularly. Observations were later made on the $7^{\text {th }}$ day. Meanwhile, the artificial insemination was carried out 8 hours after estrus was noticeable, marked by the release of mucus (Figure 1).

The second group of cows was doubly injected with $5 \mathrm{ml}$ of $\mathrm{PGF}_{2} \alpha$ intramuscularly on the first day, followed by the injection of $5 \mathrm{ml}$ $\mathrm{PGF}_{2} \alpha$ on the $11^{\text {th }}$ day. The artificial insemination was carried out 8 hours after estrus was noticeable, marked by the release of mucus on the second $\mathrm{PGF}_{2} \alpha$ injection on the $13^{\text {th }}$ day (Figure 2). 
Yendraliza et al./Animal Production. 21(2):71-80, 2019

Accredited by Kemenristek Dikti No 32a/E/KPT/2017. ISSN 1411-2027

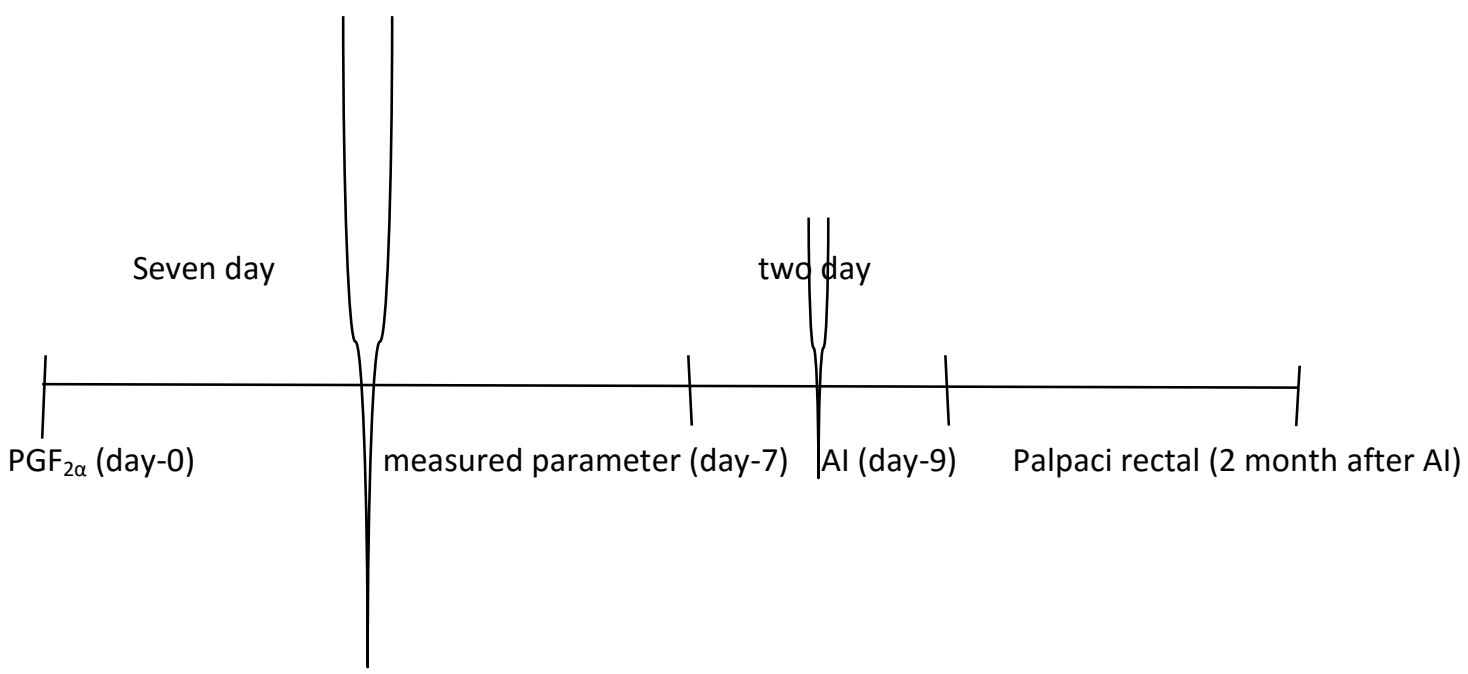

Figure 1. Synchronization schema used to single $\mathrm{PGF}_{2} \alpha$

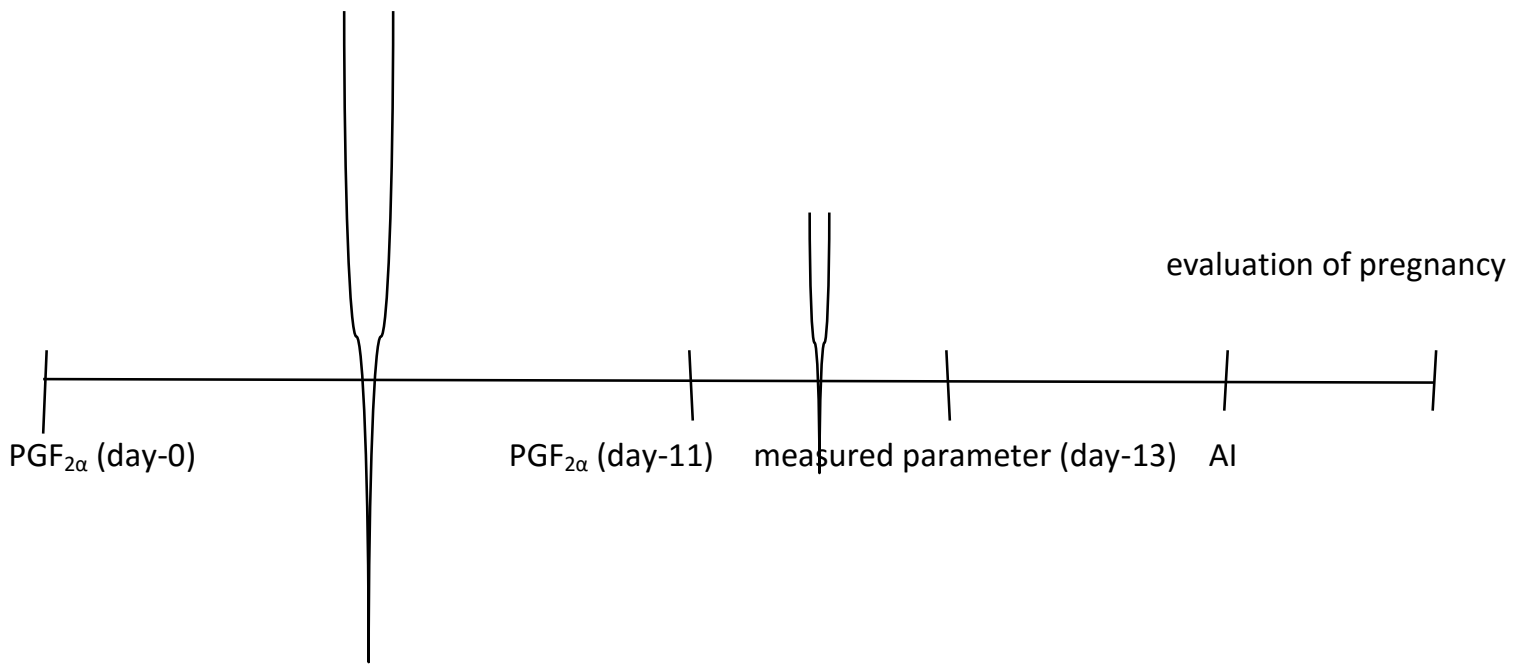

Figure 2. Synchronization schema used to double $\mathrm{PGF}_{2} \alpha$

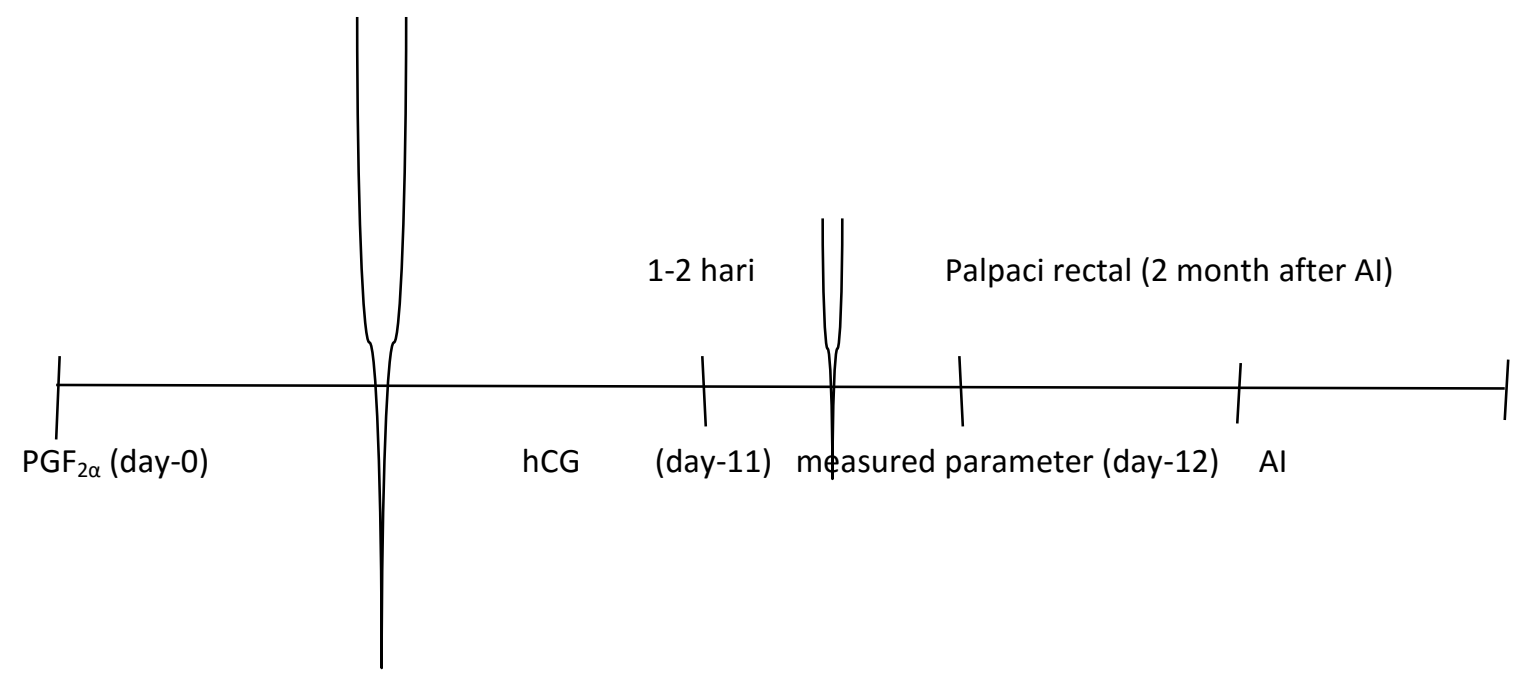

Figure 3. Synchronization schema used to combination hCG with $\mathrm{PGF}_{2} \alpha$ 
The third group of cattle was injected with $5 \mathrm{ml} \mathrm{PGF} 2 \alpha$ intramuscularly on the first day. The cows were then injected with hCG $(1,500$ IU hCG (Chorulon ${ }^{\mathrm{TM}}$, Intervet, Boxmeer, Holland) when inseminated on day 11 (Figure $3)$.

The artificial insemination was conducted by certified inseminators from the Department of Agriculture and Animal Husbandry Bengkalis. The pregnancy examination was carried out 60 days after insemination by officers from the Bengkalis Department of Agriculture and Animal Husbandry.

Parameters measured in this study included:

1. The onset of estrus (hour) is the time interval between the second injection of PGF2 $\alpha$ and the first appearance of estrus, or the time female cattle ready to mate, or the discharge of mucus from the vulva.

2. The duration of estrus (hour) is the time interval between the first observation of estrus and the end of estrus marked from the start to the end of female mating.

3. The estrus percentage is total animals in estrus cycle divided by total animals given treatment, multiplied by $100 \%$

4. Service per conception (total straws used by total conceived animals)

5. Conception rates (total pregnant animals divided by total inseminated animals)

\section{Data Analysis}

The data were analyzed in two factors randomized block design with three replications. The different middle values between treatments ( $F$ count $>F$ table $(\alpha=$ $0.05)$ or $(\alpha=0.01)$ were tested using Duncan Multiple Range Test (DMRT) based on Steel et al. (1991).

\section{Results and Discussion}

Analysis of variance result showed that there was no significant effect from the interaction between cows and different types of hormone on estrus speed, estrus length, conception rate and service per conception (Table 1). Bali cattle, Limousin cattle, and Rambon cattle demonstrated different estrus length and conception rates, but the estrus speed was not significantly different (Figure 4). The estrus of Bali cattle and Limousin cattle was longer than that of Rambon cattle (13.9 and 13.11 vs 12.11 ). Also, the pregnancy rate of Bali cattle and Limousin cattle was higher than that of Rambon cattle (55.0 and 54.89 vs 30.78).

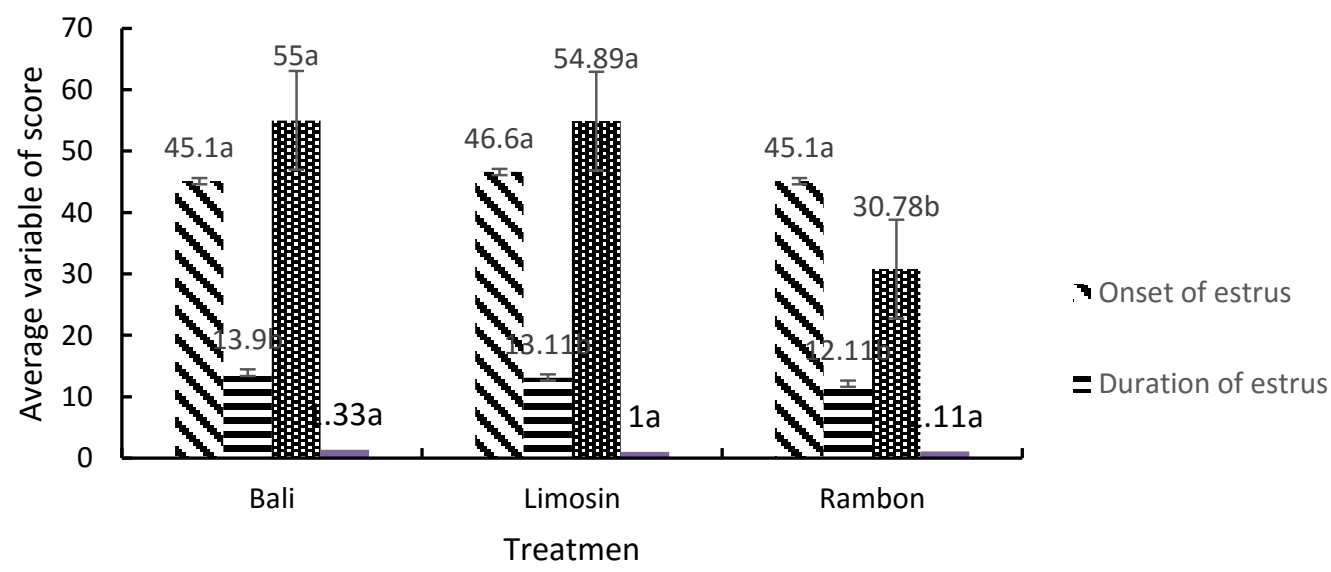

Figure 4. The average of influence of cattle on the onset of estrus, estrus duration, conception rates, and $\mathrm{S} / \mathrm{C}$ 
Table 1. Average onset of estrus, estrus duration, conception rates, and service per conception in different cattle and synchronization hormone

\begin{tabular}{|c|c|c|c|c|c|}
\hline \multirow{2}{*}{ Variable } & \multirow{2}{*}{ Cattle } & \multicolumn{3}{|c|}{ Hormones } & \multirow{2}{*}{ Average } \\
\hline & & 1 & 2 & 3 & \\
\hline \multirow{4}{*}{ Onset of estrus } & Bali & 44.7 & 44.7 & 46.0 & 45.1 \\
\hline & Limosin & 45.3 & 45.3 & 46.3 & 46.6 \\
\hline & Rambon & 44.7 & 44.7 & 46.0 & 45.1 \\
\hline & Average & $44.9^{a}$ & $44.9^{\mathrm{a}}$ & $46.1^{b}$ & \\
\hline \multirow{4}{*}{ Estrus Duration } & Bali & 13.0 & 14.0 & 14.7 & $13.9^{\mathrm{a}}$ \\
\hline & Limosin & 12.7 & 13.3 & 13.3 & $13.11^{\text {ba }}$ \\
\hline & Rambon & 12 & 10.7 & 13.7 & $12.11^{b}$ \\
\hline & Average & $12.5^{b}$ & $12.7^{b}$ & $13.9^{\mathrm{a}}$ & \\
\hline \multirow{4}{*}{ Conception Rates } & Bali & 54.7 & 50.3 & 60.0 & $55.0^{\mathrm{a}}$ \\
\hline & Limosin & 49.3 & 55.0 & 60.3 & $54.89^{\mathrm{a}}$ \\
\hline & Rambon & 27.3 & 30.7 & 34.3 & $30.78^{b}$ \\
\hline & Average & $43.7^{a}$ & $45.3^{\mathrm{ab}}$ & $51.6^{b}$ & \\
\hline Service per & Bali & 1.3 & 1.3 & 1.3 & 1.33 \\
\hline \multirow[t]{3}{*}{ conception } & Limosin & 1.0 & 1.0 & 1.0 & 1 \\
\hline & Rambon & 1.0 & 1.2 & 1.2 & 1.11 \\
\hline & Average & $1.1^{\mathrm{a}}$ & $1.2^{\mathrm{a}}$ & $1.2^{\mathrm{a}}$ & \\
\hline
\end{tabular}

Note: Different superscripts on the same column denote significant differences $(P<0.05)$

1: single dose of $\mathrm{PGF}_{2} \alpha, 2$ : double dose of $\mathrm{PGF}_{2} \alpha, 3$ : combination of $\mathrm{PGF}_{2} \alpha$ and hCG

The type of hormone used affected the duration of estrus, the speed of estrus and the pregnancy rate but did not affect the $S / C$ value (Figure 5). The speed of estrus after the single use of the $\mathrm{PGF}_{2} \alpha$ hormone was the same as what was found after the use of $\mathrm{PGF}_{2} \alpha$ twice. The combination of $\mathrm{PGF}_{2} \alpha$ and hCG hormones; however, brought about a longer estrus speed compared to the result of one-time $\mathrm{PGF}_{2} \alpha$ hormone injection and double $\mathrm{PGF}_{2} \alpha$ injection (46.1 vs 44.9 hours). The length of estrus in the single injection of the $\mathrm{PGF}_{2} \alpha$ hormone was the same as that of double $\mathrm{PGF}_{2} \alpha$ injection. Combining $\mathrm{PGF}_{2} \alpha$ and hCG hormones produced estrus longer than the estrus after only injecting $\mathrm{PGF}_{2} \alpha$ hormone once and $\mathrm{PGF}_{2} \alpha$ twice (13.9 vs 12.5-12.7 hours). Injecting $\mathrm{PGF}_{2} \alpha$ hormone once and $\mathrm{PGF}_{2} \alpha$ twice produced the same conception rate (43.7 $45.3 \%)$. In addition, the combination of $\mathrm{PGF}_{2} \alpha$ and hCG hormones produced higher rates of pregnancy compared to the use of $\mathrm{PGF}_{2} \alpha$ hormone once and $\mathrm{PGF}_{2} \alpha$ twice $(51.6 \%$ vs 43.7- 45.3\%).
The type of cow does not affect the type of hormone used in synchronization on the onset of estrus, duration of estrus, conception rate and $\mathrm{S} / \mathrm{C}$ because hormone activity is attributed to the reproduction state of the livestock rather than cattle breed (Hasan et al., 2018). In this case, hormonal patterns are influenced by the physical condition of the livestock (Ciccioli et al., 2003).

The follicular phase of cows determines the work of $\mathrm{PGF}_{2} \alpha$ hormones which is regression corpus luteum (Jainudeen and Hafez, 2016). $\mathrm{PGF}_{2} \alpha$ performs as a vasoconstrictor that drastically inhibits blood flow to the ovary and causes regression of the corpus luteum. This regression is followed by a decrease in the progesterone hormone, which will trigger anterior pituitary to the release of FSH and LH hormones. This condition, in turn, will initiate the growth and maturation of the follicles to ovulation within the next 2-4 days (Hafez et al., 2016). 


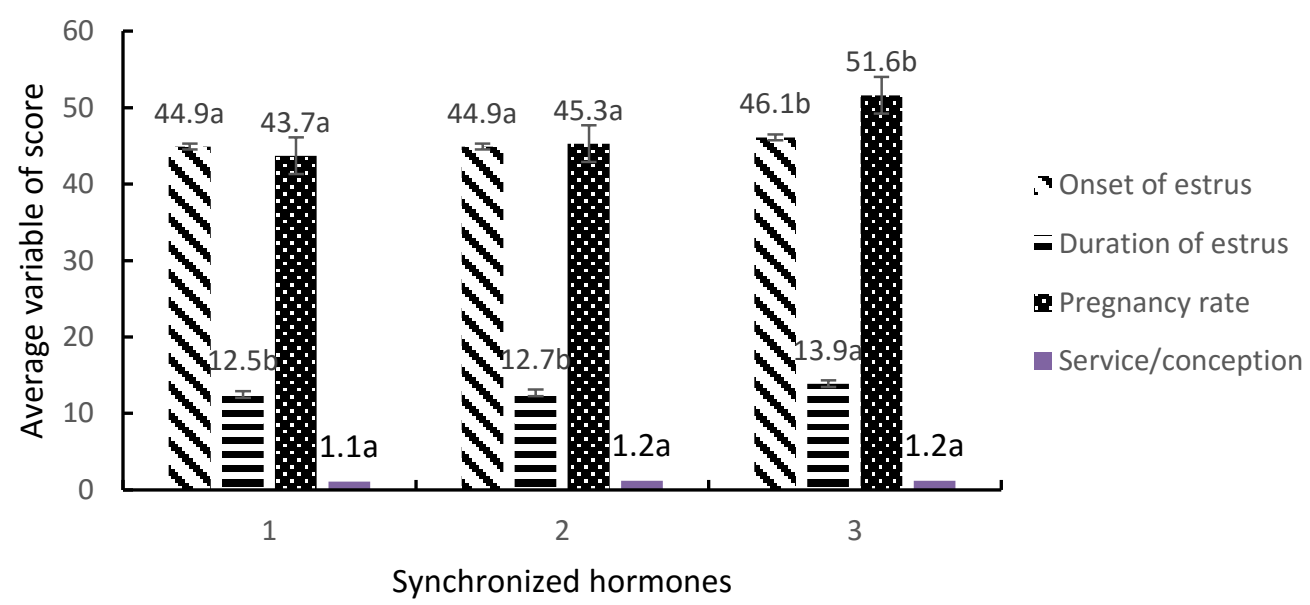

Figure 5. The average of influence of hormones on the onset of estrus, estrus duration, conception rates, and $\mathrm{S} / \mathrm{C}$

\section{The Influence of Cow types on the Measured Parameters}

Bali cattle, Rambon cattle and Limousin cattle in this study showed the same onset of estrus (Figure 5) which may be due to similar body conditions. The results of the rectal palpation examination of their reproductive conditions showed that the cows did not suffer from any reproductive disorders, demonstrating a normal working physiological mechanism. Moreover, the cows (all breeds) in this study have calved. Malik et al. (2018) stated that the Bali-cows responded better than Bali-heifers did. The environment is one of the factors influencing the emergence of heat (Nanda et al., 2003). This research selected cattle traditionally raised in the countryside. The onset of estrus in this study was different from $18.43 \pm 0.48$ hours in Jersey cows (Bhat and Bhattacharyya, 2012), and 20.07 - 21.458 hours in India cattle (Ahmed et al., 2016). The onset of estrus in this study was within the normal range, i.e. 2-3 days after the injection of PGF2 $\alpha$ (Hafez and Hafez, 2016). Malik et al. (2013) stated that parity did not significantly affect the percentage of estrus in Bali-cow and cross breed Ongole cattle.
On the other hand, Bali cattle and Limousin cattle have the duration of estrus but differ from Rambon cattle in the instance. This difference, however, was still within the normal range of 18 hours (Jainudeen and Hafez, 2016). De Rensis et al. (2010) stated that the duration of estrus was influenced by non-treatment factors such as livestock conditions. The presence of estrogen during estrus determined the extent of the estrus (Gordon, 2017). The high frequency of LH enables the dominant follicles to continue growing and secrete estrogen and inhibin. If there is an increase in FSH concentration on a large follicle from one wave that stimulates the growth of new follicle groups, de Graaf's follicles will produce more estrogen. Once estrogen has reached its maximum level, LH will be released and hence ovulation (Islam, 2011).

Conception rates (CR) of Bali cattle and Limousin cattle are the same, but different from that of Rambon cattle due to different duration of estrus. The duration of estrus that is too short or too long will affect the spread of ovulation while sperm works in a relatively short time (Hafez and Hafez, 2016). Gordon 
(2017) maintains that pregnancy rate is influenced by female fertility, the quality of semen, inseminator skills and the accuracy of estrus detection. The difference in pregnancy rates in Bali, Limousin, and Rambon Cattle is also due to different reproductive management (Nanda et al., 2003). Variations in CR scores are influenced by livestock conditions, heat detection, and reproductive management that affect livestock fertility and conception scores (Jainudeen and Hafez, 2016). The conception rates of cattle in this study are different from Aceh cattle (60\%) as noted by Efendi et al. (2015), Bali cattle (46.03\%) as found by Said et al. (2014) and Rambon cattle (90\%) as suggested by Puspitasari et al. (2018). The difference may be due to different reproductive management. In this study, the local cattle are those kept in rural areas with locally available feed (Nanda et al., 2003).

The type of cow did not affect service per conception of cattle in this study. The $\mathrm{S} / \mathrm{C}$ was within the normal range (Jainudeen and Hafez, 2016). However, the $S / C$ values were different from Indonesia's parent cows (1.50) in Mardiansyah et al. (2016) and Boyolali Friesian Holstein (1.7 times) in Wicaksono et al. (2018). The contributing factors to variations in S/C values include inseminator skills, artificial insemination time, and the farmers' knowledge in detecting heat.

\section{The Effect of Hormones on the Measured Parameters}

The single and double injection of $\mathrm{PGF}_{2} \alpha$ in cattle at Langkat village produced estrus which is faster than the combination of $\mathrm{PGF}_{2} \alpha+$ hCG hormone injection ( 44.9 hours vs 46.1 hours), which may due to different follicular or luteal conditions of the tested livestock which varies the occurrence of estrus. These conditions affect the efficiency of the estrus synchronization protocol. Adding $\mathrm{PGF}_{2} \alpha$ hormones to hCG is only effective insofar as there are a single acceptor cattle that has a developing corpus luteum, and the addition of hCG will trigger the release of LH leading to ovulation and the start of the cycle because $\mathrm{PGF}_{2} \alpha$ has started working to lyse $\mathrm{CL}$ on the first injection. Later, hCG releases FSH, creating a new group of follicles (Pursley et al., 1997). Previous studies reported that $P \mathrm{PF}_{2} \alpha$ is antigonadotropin, both in the bloodstream and in CL receptors (De Rensis et al., 2010), and adding hCG is useful for ovulation induction and the formation of corpora lutea (CL) accessories (Keskin et al. 2010). The onset of estrus in this study was different from that of Kaim et al. (2003) in dairy cattle (50.08-46.1 hours vs 30-40 hours) and Mardiansyah et al. (2016) that the onset of estrus in Bali cattle after synchronization is 41.5 hours. Saili et al. (2017) stated that differences in the start of heat in livestock were caused by nontreatment factors such as livestock conditions. Moreover, the concentrations of progesterone and estrogen in the blood may also contribute to the difference. Hafez et al. (2016) argued that it is the levels of estradiol hormones in the micro follicle environment undergoing differentiation for dominant follicle formation that make a difference. The reason for this is that the existing dominant follicles will grow immediately when the blood levels of progesterone decrease, FSH levels begin to increase, and the level of estrogen produced by the follicle is not enough for female cattle to mate.

The use of a single injection and double injection of $\mathrm{PGF}_{2} \alpha$ on cattle in this study resulted in a shorter estrus compared to the combined injection of $\mathrm{PGF}_{2} \alpha$ and hCG (12.412.7 hours vs 13.9 hours). Cow heat lasts 12 24 hours and differences are due to variations during estrous. In cows treated with hCG during the insemination, FSH levels in the blood decreased but LH levels increased. Shortly before ovulation, the follicle enlarges, while turgid and the ovum mature. The estrus 
ends approximately at the rupture of ovary follicle or at the start of ovulation (Hafez and Hafez, 2016). The duration of estrus in the combined PGF $_{2} \alpha$ and hCG is because hCG does not directly affect the ovary (Navanukraw et al., 2015). Instead, the hormones produced by the hypothalamus stimulate the synthesis and release the follicle stimulating hormone (FSH) and luteinizing hormone (LH) from Anterior Pituitary (Araujo et al., 2009). Hafez et al. (2016) stated that the Gonadotropin-releasing hormone $(\mathrm{GnRH})$ regulates gonadotropin secretion that is also called $\mathrm{LH} / \mathrm{FSH}$ releasing hormone (LH/FSH-RH). Injecting $\mathrm{PGF}_{2} \alpha$ will increase estradiol secretion which causes positive feedback control to the hypothalamus in the follicular phase. As a result, it moves $\mathrm{FSH}$ peak secretion to trigger the growth of discovery follicles so that the symptoms of lust last longer.

The duration of estrus in this study is notably different from what Malik et al. (2018) noted (12.4-13.9 hours vs 8.51 hours) in PO cattle in Kendal using MPA hormone, and Yendraliza et al. (2012) in Kampar buffalo (12.4-13.9 hours vs 10.4-18.0 hours) using $\mathrm{GnRH}$ and $\mathrm{PGF}_{2} \alpha$. The different abilities of cattle to reduce progesterone concentration may attribute to different estrus length. The decline of progesterone will provide feedback to the hypothalamus and anterior pituitary, so $\mathrm{FSH}$ will be secreted and stimulate folliculogenesis, heat, and ovulation Yendraliza et al., 2015). Furthermore, Toelihere (1985) argued that what influences the duration of estrus are the different hormonal preparations and dosages given, the patterns of observation factors, the conditions of livestock, and the feed.

After the second injection of $\mathrm{PGF}_{2} \alpha$, all cows demonstrated $100 \%$ estrus with obvious symptoms such as vomiting, swelling, vulva mucus release, red and warm vulva, and the cows being restless and "riding" others. Therefore, $\mathrm{PGF}_{2} \alpha$ can lysis the luteal corpus in buffalo to respond well to the injection of $\mathrm{PGF}_{2} \alpha$.

Furthermore, $\mathrm{PGF}_{2} \alpha$ in this study resulted in insignificant $S / C$; that is, the $S / C$ scores of the cows are not statistically different. This $\mathrm{S} / \mathrm{C}$ score is similar to $1.40 \pm 0.50$ (Mardiansyah et al., 2016), which is still within the normal range (Jainudeen and Hafez, 2016). Nanda et al. (2003) reported that lower conception rates resulted from factors such as lactation status, postpartum intervals, and nutrition and livestock management.

The conception rates of cows receiving a combination of $\mathrm{PGF}_{2} \alpha+$ hCG injection were higher than the rates of cows receiving single $\mathrm{PGF}_{2} \alpha$ and double $\mathrm{PGF}_{2} \alpha$ injection because hCG contains FSH and LH expected to increase ovulation of cows in one estrus. Akhtar et al. (2013) suggests that hCG may increase the conception rates of buffaloes up to $100 \%$. In addition, Navanukraw et al. (2015) maintained that the administration of hCG in the synchronization of dairy cows was more effective in increasing pregnancy rates.

\section{Conclusions}

Bali cattle demonstrated better fertility than Limousin and Rambon cattle, with the best synchronization method being the combination of $\mathrm{PGF}_{2} \alpha$ and $\mathrm{hCG}$ as opposed to the single and double doses of $\mathrm{PGF}_{2} \alpha$.

\section{Acknowledgment}

The authors would like to thank Balitbang Bengkalis for financial support and the provision of research location. The authors also thank Inseminator Siak Kecil Team, especially Mr. Slamet and Mr. Jailani, for their kind assistance throughout the experiment. There is no conflict of interest in this study.

\section{References}

Ahmed, N., D. Kathiresan, F. A. Ahmed, K. Lalrintluanga, P. Mayengbam and J. M. Gali. 2016. Pattern of induced estrus and conception 
rate following ovsynch and ovsynch based gonadotropin-releasing hormone treatments initiated on day 6 of the estrous cycle in repeat breeding crossbred cows. Veterinary World. 9(4): $\quad 342-345 . \quad$ https://doi.org/10.14202/ vetworld.2016.342-345

Akhtar, M. S., L. A. Lodhi, A. A. Farooq, M. M. Ayaz, S. Murtaza, M. Arshad and M. Hussain. 2013. Effect of different doses of hCG at $\mathrm{Al}$ on pregnancy rates of repeat breeder Nili-Ravi buffalo. Buffalo Bulletin. 32(2):362-365.

Araujo, R. R., O. J. Ginther, J. C. Ferreira, M. M. Palhão, M. A. Beg and M. C. Wiltbank. 2009. Role of follicular estradiol-17beta in the timing of luteolysis in heifers. Biology of Reproduction. 81(2): 426-437. https://doi.org/10.1095/ biolreprod.108.073825

Bhat, F. A. and H. K. Bhattacharyya. 2012. Oestrus Duration and Status of Reproductive Organs in Repeat Breeding Cows. Iranian Journal of Applied Animal Science. 2(3): 295-299.

BPS (Badan Pusat Statistik). 2017. Bengkalis dalam angka. Bengkalis

Ciccioli, N. H., R. P. Wettemann, L. J. Spicer, C. A. Lents, F. J. White and D. H. Keisler. 2003. Influence of body condition at calving and postpartum nutrition on endocrine function and reproductive performance of primiparous beef cows1,2. Journal of Animal Science. 81(12): 3107-3120. https://doi.org/10.2527/ 2003.81123107x

De Rensis, F., F. López-Gatius, I. García-Ispierto and M. Techakumpu. 2010. Clinical use of human chorionic gonadotropin in dairy cows: An update. Theriogenology. 73(8): 1001-1008. https://doi.org/10.1016/j.theriogenology.2009. 11.027

Efendi, M., T. N. Siregar, C. N. Thasmi and A. Sayuti. 2015. Conception Rates of Local Cows after Induction with Ovsynch Protocols. Journal Medika Veterinaria. 9(2): 159-162.

Gordon, I. 2017. Reproductive technologies in farm animals. $\mathrm{CABI}$

Hafez, E. S. E. and B. Hafez. (2016a). Folliculogenesis, Egg Maturation, and Ovulation. In Reproduction in Farm Animals (pp. 68-81). Baltimore, Maryland, USA: Lippincott Williams \& Wilkins. https://doi.org/10.1002/9781119265306.ch5

Hafez, E. S. E. and B. Hafez. (2016b). Reproductive Cycles. In Reproduction in Farm Animals (pp. 55-67). Baltimore, Maryland, USA: Lippincott Williams \& Wilkins. https://doi.org/10.1002/ 9781119265306.ch4.

Hafez, E. S. E., M. R. Jainudeen and Y. Rosnina. 2016. Hormones, Growth Factors, and
Reproduction. In Reproduction in Farm Animals (pp. 31-54). Baltimore, Maryland, USA: Lippincott Williams \& Wilkins. https://doi.org/10.1002/9781119265306.ch3

Hasan, M., M. Hassan, R. Mohanta, M. Miah, M. Rashid and N. Juyena. 2018. A comparative study on productive, reproductive and ovarian features of repeat breeder and normal cyclic cows in the selected areas of Bangladesh. Journal of Advanced Veterinary and Animal Research. 5(3): 324. https://doi.org/ 10.5455/javar.2018.e283

Islam, R. 2011. Synchronization of estrus in cattle: A review. Veterinary World. 4(3): 136-141. https://doi.org/10.5455/vetworld.2011.136141

Jainudeen, M. R. and B. Hafez. 2016. Reproductive Failure in Males. In Reproduction in Farm Animals. pp: 279-289. Baltimore, Maryland, USA: Lippincott Williams and Wilkins. https://doi.org/10.1002/9781119265306.ch18

Jainudeen, M.R. and E. S. E. Hafez. 2016. Reproductive Failure in Females. In Reproduction in Farm Animals. pp: 259-278. Baltimore, Maryland, USA: Lippincott Williams and Wilkins. https://doi.org/10.1002/ 9781119265306.ch17

Kaim, M., A. Bloch, D. Wolfenson, R. Braw-Tal, M. Rosenberg, H. Voet and Y. Folman. 2003. Effects of GnRH Administered to Cows at the Onset of Estrus on Timing of Ovulation, Endocrine Responses, and Conception. Journal of Dairy Science. 86(6): 2012-2021. https://doi.org/ 10.3168/jds.s00220302(03)73790-4

Keskin, A., G. Yilmazbas-Mecitoglu, A. Gumen, E. Karakaya, R. Darici and H. Okut. 2010. Effect of hCG vs. GnRH at the beginning of the Ovsynch on first ovulation and conception rates in cyclic lactating dairy cows. Theriogenology. 74(4): 602-607. https://doi.org/10.1016/ j.theriogen ology.2010.03.009

Malik, A., A. Gunawan, A. Jaelani, R. Budirahman and S. Erlina. 2013. Pakistan Veterinary Journal. Pakistan Veterinary Journal. 33(4): 446-449. https://doi.org/10.1097/QCO.0b013e32836381 04.

Malik, A., Heppy, M. S. Djaya and N. Widaningsih. 2018. Comparing Response of Estrus Synchronization in the Heifers and Cows on Estrus Initial, Duration of Estrus and Pregnancy Rate Bali Cattle. Advances in Animal and Veterinary Sciences. 6(6): 242-245.

Mardiansyah, E. Yuliani and S. Prasetyo. 2016. Respon tingkah laku birahi, service per conception, non return rate, conception rate pada Sapi Bali dara dan induk yang 
disinkronisasi birahi dengan hormon Progesteron. Jurnal IImu Dan Teknologi Peternakan Indonesia. 2(1): 134-143.

Nanda, A. S., P. S. Brar and S. Prabhakar. 2003. Enhancing reproductive performance in dairy buffalo: major constraints and achievements. Reproduction. Supplement (61): 27-36.

Navanukraw, C., V. Khanthusaeng, A. Kraisoon, D. Suwannarit, C. Jarassaeng and S. Aiumlamai. 2015. Synchronization of ovulation with human chorionic gonadotropin in lactating dairy cows with ovarian cysts during heat stress. Tropical Animal Health and Production. 47(5):945-951. https://doi.org/10.1007/s11250-015-0813-8

Pursley, J. R., M. R. Kosorok and M. C. Wiltbank. 1997. Reproductive Management of Lactating Dairy Cows Using Synchronization of Ovulation. Journal of Dairy Science. 80(2): 301-306. https://doi.org/10.3168/jds.s00220302(97)759 38-1.

Purwantara, B., R. R. Noor, G. Andersson, and H. Rodriguez-Martinez. 2012. Banteng and Bali cattle in Indonesia: Status and forecasts. Reproduction in Domestic Animals. 47(SUPPL. 1):2-6. https://doi.org/10.1111/j.1439-0531. 2011.01956.

Puspitasari, I. F., N. Isnaini, A. P. A. Yekti and T. Susilawati. 2018. Tampilan Reproduksi Sapi Rambon Betina pada Paritas yang Berbeda. Journal of Tropical Animal Production. 19(2): 80-86.https://doi.org/10.21776/ub.jtapro.2018 .019 .02 .2

Said, S., C. Arman and B. Tappa. 2014. Conception Rates and Sex Concomitant of Bali Calves Following Oestrus Synchronization and Artificial Insemination of Frozen- Sexed Semen Under
Farm Conditions. Journal of the Indonesian Tropical Animal Agriculture. 39(1):10-16. https://doi.org/10.14710/jitaa.39.1.10-16

Saili, T., L. O. Baa, A. Napirah and I. W. Sura. 2017. Pregnancy rate of Bali Cows following Artificial Insemination using Chilled Sexed Sperm under Intensive Management in Tropical Area. In The 7th International Seminar on Tropical Animal Production, Contribution of Livestock Production on Food Sovereignty in Tropical Countries September 12-14, Yogyakarta, Indonesia. pp: 738-742.

Steel, R. G. D., J. H. Torrie and B. Sumantri. 1991. Prinsip dan prosedur statistika: suatu pendekatan biometrik. Gramedia Pustaka Utama.

Toelihere, M. R. 1985. Fisiologi reproduksi pada ternak. Angkasa.

Wicaksono, A. M., A. Pramono, A. Susilowati, Sutarno, N. Widyas and S. Prastowo. 2018. The number of service per conception of Indonesian Friesian Holstein with artificial insemination in Selo, Boyolali, Central Java, Indonesia. In IOP Conference Series: Earth and Environmental Science. 142:6-10. https://doi.org/10.1088/ 17551315/142/1/012004.

Yendraliza, Y., B. Zespin, Z. Udin, J. Jaswandi and C. Arman. 2012. Penampilan Reproduksi Kerbau Post Partum pada Berbagai Level GnRH yang disinkronisasi dengan PGF $2 \alpha$. JITV. 17(2):107111.

Yendraliza, B. P. Zesfin, Z. Udin, Jaswandi and C. Arman. 2015. Estrus Synchronization in Swamp Buffaloes. In Purohit G.N (Ed.) Bubaline Theriogenology. (p. 28). Ithaca NY: International Veterinary Information Service. 